\title{
Development of Integrated Fertilizer Management Strategies in Lentil for Higher Productivity in the South-Western Region of Bangladesh
}

\author{
Md. Shahriar Kobir ${ }^{1}$, Md. Harun-Or-Rashid ${ }^{2} \&$ Sharif Ahmed $^{3}$ \\ ${ }^{1}$ Bangladesh Agricultural Research Institute, Bangladesh \\ ${ }^{2}$ International Maize and Wheat Improvement Center, Bangladesh Office, Bangladesh \\ ${ }^{3}$ International Rice Research Institute, Bangladesh Office, Bangladesh \\ Correspondence: Md. Shahriar Kobir, Bangladesh Agricultural Research Institute, Bangladesh. E-mail: \\ shahriar1302027@gmail.com
}

Received: May 17, 2020 Accepted: June 4, 2020 Online Published: June 12, 2020

\begin{abstract}
Due to the lack of optimum fertilizer management in low organic matter content soil is one of the limiting factors to the lower yield and productivity of lentil in Bangladesh. To increase the yield and maintain the sustainability of lentil production in the highly intensive cropping areas of Bangladesh the development of integrated fertilizer management is urgent. An experiment was conducted at Regional Agricultural Research Station, Jashore, Bangladesh during the rabi season of 2018-2019 to develop an integrated fertilizer management strategies for lentil in low organic matter content soil. The experiment was laid out in a split plot design where different fertilizer management techniques were allocated in the main-plots and different varieties were allocated in the sub-plots. There were five fertilizer management (FM) techniques such as FM1-Vermicompost 1t ha ${ }^{-1}+$ (inorganic P:K:S @ 23:6:10 $\left.\mathrm{kg} \mathrm{ha}^{-1}\right)+2 \%$ DAP foliar spray, FM2- Vermicompost $1 \mathrm{t} \mathrm{ha}^{-1}+\left(\right.$ inorganic P:K:S @ 24:6:10 kg ha $\left.\mathrm{kg}^{-1}\right)+1 \%$ DAP foliar spray, FM3- (inorganic N:P:K:S @ 20:40:20:10 $\mathrm{kg} \mathrm{ha}^{-1}$ ) and no DAP foliar spray, FM4- Vermicompost 1t ha ${ }^{-1}+$ (inorganic P: K: S @ 25:6:10 $\mathrm{kg} \mathrm{ha}^{-1}$ ) and no DAP foliar spray, FM5- control and there were three varieties such as V1-BARI Masur-6, V2-BARI Masur-7 and V3-BARI Masur-8.

The highest plant height $(\mathrm{cm})$, plant density at harvest, leaf chlorophyll index, grain yield and the lowest days to $50 \%$ flowering and Stemphyliumblight disease score was observed from the treatment combination FM1V3 (vermicompost $1 \mathrm{t} \mathrm{ha}{ }^{-1}+$ (inorganic P:K:S @ 23:6:10 $\mathrm{kg} \mathrm{ha}^{-1}$ ) +2\% DAP foliar spray with lentil variety BARI Masur-8). The next best treatment combinations were FM1V2 (vermicompost 1t ha-1 + (inorganic P:K:S @ 23:6:10 kg ha-1) + 2\% DAP foliar spray with lentil variety BARI Masur-7) and FM1V1 (vermicompost $1 \mathrm{t}$ ha-1 + (inorganic P:K:S@ 23:6:10 kg ha-1) + 2\% DAP foliar spray with lentil variety BARI Masur-6), respectively. Integrated fertilizer management technique such as vermicompost 1t ha ${ }^{-1}+$ inorganic P:K:S @ 23:6:10 kg ha $\mathrm{kg}^{-1}+$ 2\% DAP foliar spray with variety BARI Masur-8 may be recommended to farmers for sustainable lentil production.
\end{abstract}

Keyword: vermicompost, organic fertilizer, foliar spray, lentil

\section{Introduction}

People consume pulses as an important source of protein throughout the world. All over the world pulses are known as the poor man's meat (Hussain, 2016). Bangladesh produces several pulses such as lentil (Lens culinaris), grasspea (Lathyrussativus), blackgram (Vignamungo), mungbean (Vignaradiata), chickpea (Cicerarietinum), pea (Peasumsativum), pigeon pea (Cajanascajan), cowpea (Vignaunguiculata) (Hussain, 2016). Lentil is one of the most ancient legume pulse and seems that it has been domesticated in the crescent about 8000 years ago (Zohary and Hopf, 2000). Among the pulses grown in Bangladesh about 41\% area is covered by lentil (BBS, 2019). Lentil in Bangladesh is mainly growing in rabi season and major growing areas are Pabna, Jashore, Kushtia, Faridpur, Rajshahi, Magura, Jhenaidah and Madaripur districts (Azad et al., 2019). In the year 2018/19, Bangladesh produced about 0.17 million tons of lentil from its 0.35 million acres land (BBS, 2019). To fulfill the domestic demand country imported about 0.43 million tons of lentil from the foreign countries (The financial express, 2020). Low yield potential of local cultivars and susceptibility to major diseases, poor fertilizer and irrigation management, and delayed sowing are the major production constraints for lentil production in Bangladesh (Sarkar, 2004). For this reason, time to time several agronomic approaches has been taken to increase the lentil's productivity. Among them agronomic soil management using plant residue, application of FYM or vermi products are well known approaches (Rudrappa et al., 2006). Soil organic matter maintaining is very important to gain the long-term 
productivity of crops including lentil (Janmohammadi et al., 2014). Vermicompost an organic fertilizer can enhance the soil organic matter and in addition, it improves the soil structure, water holding capacity, bulk density and enhances the microbial activity in soil (Adolph et al., 2002).

Chemical fertilizers recommended for lentil are not always works effectively due to the soil situations. Sometimes soil are not in favor to absorb of plant nutrient or sometime quick supply of essential nutrients are not conducive to soil, therefore foliar application of nutrient is a solution to that problem in that stage (Salisbury and Ross, 1985). Foliar spray of fertilizer helps the nutrient to go through directly in the site of food synthesis thus less wastage and quick supplement of nutrient which hasten sudden growth of lentil and it reduce the requirement of large quantity of fertilizer (Das and Jana, 2015). Foliar application of urea at 50\% flowering stage enhanced the yield found by (Palta et al. 2005) and (Zeidan, 2003). Leaf senescence begins earlier in lentil before completing maturity and it hamper in the process of source to sink deployment resulted in yield reduction where nitrogen spray can delay the leaf senescence that hasten the productivity (Das and Jana, 2015).

Chemical fertilizers are essential for lentil but combination of chemical fertilizer, organic fertilizer or manure, foliar spray of nitrogenous and phosphorus fertilizer provides higher productivity over individual source of nutrient (Math et al., 2018). So it is obvious that there is a scope to increase lentil productivity by applying judicious fertilizer management including inorganic fertilizer, organic fertilizer and foliar spray of fertilizer. But the research work related to combined application of organic, inorganic and foliar spray of fertilizer in lentil is limited.Therefore, this experiment was initiated to investigate and to develop appropriate integrated fertilizer management strategies in lentil for its higher productivity and sustainability.

\section{Materials and Methods}

The experiment was conducted at Regional Agricultural Research Station $\left(23^{\circ} 18^{\prime}\right.$ latitude and $89^{\circ} 18^{\prime}$ longitude with the altitude of $19 \mathrm{~m}$ ), Bangladesh Agricultural Research Institute, Jashore, Bangladesh during the rabi 20182019 season. The trial site falls under the Agro-Ecological Zone number eleven (AEZ-11) called the High Ganges River Floodplain (FRG, 2012). The climate at the experimental site is subtropical monsoon nature with high rainfall during May to October and scanty rainfall during November to April. Annual average rainfall is $\sim 1600$ $\mathrm{mm}$. About $90 \%$ of the total rainfall occurs from May to October and the distribution of the rainfall is uneven and unpredictable. Monthly average temperature ranges from $20{ }^{\circ} \mathrm{C}$ in January to $35^{\circ} \mathrm{C}$ in April. The soil of the experimental field is sandy loam in texture and slightly alkaline in reaction $(\mathrm{pH} 7.5)$ having organic carbon of $1.6 \%$. The experiment was conducted in split plot design in where different fertilizer management options were placed in main plots and different varieties were placed in subplots.

Table 1. The treatments details are explained

\begin{tabular}{|c|c|}
\hline $\begin{array}{l}\text { Mainplot treatment:Fertilizer management } \\
\text { (FM) options }\end{array}$ & Treatment details \\
\hline $\begin{array}{l}\text { FM1- Vermicompost } 1 \mathrm{t} \mathrm{ha}^{-1}+\text { inorganic } \\
\mathrm{P}: \mathrm{K}: \mathrm{S} @ 23: 6: 10 \mathrm{~kg} \mathrm{ha}^{-1}+2 \% \text { DAP foliar } \\
\text { spray }\end{array}$ & $\begin{array}{l}\text { Total vermicompost and other inorganic fertilizers were mixed } \\
\text { with soil during the final land preparation and foliar spray of DAP } \\
\text { was applied at } 50 \% \text { flowering stage. }\end{array}$ \\
\hline $\begin{array}{l}\text { FM2- Vermicompost } 1 \mathrm{t} \mathrm{ha}^{-1}+\text { inorganic } \\
\mathrm{P}: \mathrm{K}: \mathrm{S} @ 24: 6: 10 \mathrm{~kg} \mathrm{ha}^{-1}+1 \% \text { DAP foliar } \\
\text { spray }\end{array}$ & $\begin{array}{l}\text { Total vermicompost and other inorganic fertilizers were mixed } \\
\text { with soil during the final land preparation and foliar spray of DAP } \\
\text { was applied at } 50 \% \text { flowering stage. }\end{array}$ \\
\hline $\begin{array}{l}\text { FM3- Inorganic N:P:K:S@20:40:20:10 } \\
\mathrm{kg} \mathrm{ha}^{-1} \text { and no DAP foliar spray }\end{array}$ & $\begin{array}{l}\text { Total inorganic fertilizers were mixed with soil duringthe final } \\
\text { land preparation. }\end{array}$ \\
\hline $\begin{array}{l}\text { FM4- Vermicompost } 1 \mathrm{t} \mathrm{ha} \mathrm{h}^{-1}+\text { inorganic P: } \\
\mathrm{K}: \mathrm{S} @ 25: 6: 10 \mathrm{~kg} \mathrm{ha}^{-1} \text { and no DAP foliar } \\
\text { spray }\end{array}$ & $\begin{array}{l}\text { Total vermicompost and other inorganic fertilizers were mixed } \\
\text { with soil during the final land preparation. }\end{array}$ \\
\hline FM5- Control & No fertilizers were used. \\
\hline Sub-plot treatment: Varieties (V) & Features \\
\hline V1: BARI Masur-6 & $\begin{array}{l}\text { Average plant height } 35-40 \mathrm{~cm} \text {, life cycle } 110-115 \text { days, } \\
\text { yield } 1800-2000 \mathrm{~kg} \mathrm{ha}^{-1} \text {, resistance to rust and Stemphyllium } \\
\text { blight disease. }\end{array}$ \\
\hline V2: BARI Masur-7 & $\begin{array}{l}\text { Average plant height } 32-38 \mathrm{~cm} \text {, yield } 1800-2100 \mathrm{~kg} \mathrm{ha}^{-1} \text {, suitable } \\
\text { for growing all over the country. }\end{array}$ \\
\hline
\end{tabular}


V3: BARI Masur-8
Fe and $\mathrm{Zn}$ enriched, life cycle 110-115 days, yield 2100-2200 kg

$\mathrm{ha}^{-1}$, resistance to rust and Stemphyllium blight disease.

The unit plot size was $12.8 \mathrm{~m}^{2}(3.28 \mathrm{~m} \times 4 \mathrm{~m})$ in where row to row distance was $40 \mathrm{~cm}$ and plant to plant distance was $5 \mathrm{~cm}$. The land was ploughed three times using a cultivator drown by a four wheels tractor. Seeds of the selected cultivars were sown on November 8, 2018 at the rate of $30 \mathrm{~kg} \mathrm{ha}^{-1}$. The seeds were treated using a fungicide namely provax @ 2.5g/kg seed. Weeds were managed by two times hand weeding at 30 DAS and 65 DAS. Fertilizers were applied as per the treatments. Irrigation was avoided. Crop was harvested on $22^{\text {th }}$ February 2019. The harvested crop was sun dried for two days and threshed manually as plot wise. The data on days to flowering, days to mature, plants height $(\mathrm{cm})$ at harvest, plant density, pods plant ${ }^{-1}$, nodules plant $^{-1}$ at $50 \%$ flowering, chlorophyll index at 50\% flowering, yield $\left(\mathrm{kgha}^{-1}\right)$, and stemphyllium blight disease score (0-5) were recorded.The analysis of variances for the measuring parameters was performed using a statistical software statistix-10 and means were compared using Tukey's HSD at alpha $=0.05$.

\section{Results and Discussion}

Days to 50\% flowering: Different fertilizer management options, varieties and their interaction significantly affect the days to $50 \%$ flowering of lentil. The highest (61) and lowest (57) days to flowering was observed in interaction FM5V1 (control with BARI Masur-6) and FM1V3 (vermicompost 1t ha ${ }^{-1}+$ inorganic P:K:S @ 23:6:10 kg ha ${ }^{-1}+$ $2 \%$ DAP foliar spray with BARI Masur-8), respectively. It may be due to quick availability of nutrient as organic source of fertilizer and direct foliar spray of nutrient was applied in FM1V3 interaction treatment. Similar result was also found by (Janmohammadi et al., 2014). He observed organic source of fertilizer and foliar application of growth regulators improves both root and total above ground plant growth.

Days to maturity:In case of fertilizer management options and varieties, days to maturity was significant but their interaction was not significant. Fertilizer management options FM5 and FM1, respectively required the highest and lowest days to maturity. Considering by the varieties, the highest days required to maturity for variety V1 and $\mathrm{V} 2$ and the lowest days for variety V3.

Plant height: Plant height of lentil differed significantly due to different fertilizer management options, different varieties and their interaction. The highest plant height $(42 \mathrm{~cm})$ was observed due to the interaction effect of FM1V3 (vermicompost 1t ha ${ }^{-1}+$ inorganic P:K:S @ 23:6:10 kg ha-1 + 2\% DAP foliar spray with BARI Masur-8) and the lowest plant height $(31 \mathrm{~cm})$ was found due to the interaction effect of FM5V3 (Control with BARI Masur6). This result is at par with the finding of (Hossain et al., 2018). They showed that foliar application of DAP increases the plant height of lentil. Enlargement of plant height in lentil as influenced by additional nitrogen adjustment was also earlier reported by (Janloo et al., 2009) and (Niri et al., 2010).

Plant density at harvest: Plant density at harvest was significantly varied due to the different fertilizer management options, varieties and their interaction. The highest (201) and lowest (69) plants $\mathrm{m}^{-2}$ was found from the interaction effect of FM1V3(vermicompost 1t ha-1 + inorganic P:K:S @ 23:6:10 kg ha-1 + 2\% DAP foliar spray with BARI Masur-8) and FM5V1 (control with BARI Masur-6), respectively.

Pods plant ${ }^{-1}$ : Fertilizer management options and varieties have significant effect on pods plant ${ }^{-1}$ but there was no significant interaction effect. (Fatema et al., 2018) states that pods plant ${ }^{-1}$ were maximum incase of 50:70:30$\mathrm{N}: \mathrm{P}: \mathrm{K}+4 \mathrm{t} \mathrm{ha} \mathrm{a}^{-1} \mathrm{FYM}$ application which is more or less similar to the present study.

Nodules plant ${ }^{-1}$ : Nodules plant ${ }^{-1}$ differed significantly due to fertilizer management options and varieties but did not differ significantly due to their interaction effect. Interaction between different FYM quantity and different growth regulator were also found non-significant by (Janmohammadi et al., 2014) in increasing of nodules plant ${ }^{1}$. (Hossain et al., 2018) revealed that foliar application of TSP in lentil increases the no. of nodules plant ${ }^{-1}$ which is similar to present findings.

Chlorophyll index: Chlorophyll index of lentil leaf was statistically significant in case of fertilizer treatments, varieties and for their interaction. The highest (23) chlorophyll index was observed in FM1V3 (vermicompost 1t $\mathrm{ha}^{-1}+$ inorganic P:K:S @ 23:6:10 $\mathrm{kg} \mathrm{ha}^{-1}+2 \%$ DAP foliar spray with BARI Masur-8) and the lowest (4) was found from the FM3V3 (inorganic N:P:K:S@ 20:40:20:10 kg ha-1 and no DAP foliar spray with BARI Masur-8) and FM5V3 (control with BARI Masur-8) interaction. Phosphorus increases the $\mathrm{N}$-fixing capacity of lentil as well as other legumes and in addition it also increases the chlorophyll content stated by (Singh et al., 2003). Foliar application of DAP supplied the nutrient phosphorus in the present study and probably this may help to increase the chlorophyll index in treatment combination FM1V3. Similar result was also found by (Janmohammadi et al., 2014). 
Lentil grain yield: Grain yield of lentil was affected significantly by the fertilizer management options, different varieties and their interaction. The highest grain yield $\left(2535 \mathrm{~kg} \mathrm{ha}^{-1}\right)$ was observed from the treatment combination FM1V3 (vermicompost 1t ha-1 + inorganic P:K:S @ 23:6:10 kg ha-1 + 2\% DAP foliar spray with BARI Masur-8) and the lowest grain yield $\left(1118 \mathrm{~kg} \mathrm{ha}^{-1}\right)$ was found from the treatment combination FM5V1(control with BARI Masur-6) interaction effect. The higher grain yield in FM1V3 treatment may be for the positive effect of organic, inorganic and foliar sprayed fertilizer on growth and development of lentil. Similar results also reported by (Das and Jana, 2015). They concluded that significantly higher seed yield was found by $2 \%$ urea spray at pre flowering stage. (Math et al., 2018) revealed that vermicompost $2 \mathrm{t} \mathrm{ha}{ }^{-1}+37.5: 75 \mathrm{~N}: \mathrm{P}_{2} \mathrm{O}_{5} \mathrm{~kg} \mathrm{ha}^{-1}$ with $2 \%$ DAP spray gives the highest grain yield which is similar to this present research work. These findings are also in agreement with the findings of (Mandal and Majumdar 2001), (Gan et al., 2005), (Rabbi et al., 2011) and (Sharma, 1999).

Stemphylium blight $(S B)$ disease score: The SB disease score differed significantly for fertilizer management options, varieties and their interaction. The highest (2.3) disease score was observed from the interaction effect of FM5V1 (control with BARI Masur-6) and the lowest score (0.0) was observed from the interaction effect of FM1V2 (vermicompost 1t ha ${ }^{-1}+$ inorganic P:K:S-23:6:10 @ $\mathrm{kg} \mathrm{ha}^{-1}+2 \%$ DAP foliar spray with BARI Masur-7). The fertilizer management options which contain organic matter and foliar spray had lower SB score than the control and it may be due to organic fertilizer make the nutrient available for the plants thus the plants become more vigorous and less susceptible to disease.

Table 2. Phenology, yield contributing characters and yield of lentil as affected by fertilizer management options

\begin{tabular}{cccccccccc}
\hline $\begin{array}{c}\text { Fertilizer } \\
\text { management } \\
\text { options }\end{array}$ & $\begin{array}{c}\text { Days to } \\
50 \% \\
\text { flowering }\end{array}$ & $\begin{array}{c}\text { Days to } \\
\text { maturity }\end{array}$ & $\begin{array}{c}\text { Plant } \\
\text { height } \\
(\mathrm{cm})\end{array}$ & $\begin{array}{c}\text { Plants } \\
\mathrm{m}^{-2} \\
(\text { no. })\end{array}$ & $\begin{array}{c}\text { Pods } \\
\text { plant } \\
1 \\
(\text { No. })\end{array}$ & $\begin{array}{c}\text { Nodules } \\
\text { plant }^{-1} \\
\left(\text { No. }^{2}\right.\end{array}$ & $\begin{array}{c}\text { Chlorophyll } \\
\text { index }\end{array}$ & $\begin{array}{c}\text { Yield } \\
\left(\mathrm{kg} \mathrm{ha}^{-}\right. \\
1)\end{array}$ & $\begin{array}{c}\text { *SB } \\
\text { disease } \\
(0-5\end{array}$ \\
\hline FM1 & $58 \mathrm{c}$ & $106 \mathrm{~b}$ & $39 \mathrm{a}$ & $192 \mathrm{a}$ & $108 \mathrm{a}$ & $76 \mathrm{a}$ & $20 \mathrm{a}$ & $2338.7 \mathrm{a}$ & $0.1 \mathrm{~b}$ \\
FM2 & $59 \mathrm{~b}$ & $107 \mathrm{~b}$ & $37 \mathrm{~b}$ & $185 \mathrm{~b}$ & $99 \mathrm{~b}$ & $69 \mathrm{~b}$ & $14 \mathrm{~b}$ & $2103.4 \mathrm{~b}$ & $0.3 \mathrm{~b}$ \\
FM3 & $59 \mathrm{~b}$ & $107 \mathrm{~b}$ & $34 \mathrm{c}$ & $138 \mathrm{c}$ & $82 \mathrm{c}$ & $62 \mathrm{c}$ & $12 \mathrm{~b}$ & $1863.2 \mathrm{c}$ & $0.2 \mathrm{~b}$ \\
FM4 & $59 \mathrm{~b}$ & $109 \mathrm{a}$ & $33 \mathrm{~d}$ & $108 \mathrm{~d}$ & $73 \mathrm{~d}$ & $59 \mathrm{c}$ & $12 \mathrm{~b}$ & $1591.6 \mathrm{~d}$ & $0.3 \mathrm{~b}$ \\
FM5 & $60 \mathrm{a}$ & $109 \mathrm{a}$ & $32 \mathrm{e}$ & $89 \mathrm{e}$ & $64 \mathrm{e}$ & $49 \mathrm{~d}$ & $8 \mathrm{c}$ & $1288.2 \mathrm{e}$ & $1.3 \mathrm{a}$ \\
\hline SE & 0.3 & 0.41 & 0.26 & 1.52 & 2.07 & 1.86 & 0.83 & 41.97 & 0.23 \\
Lsd (.05) & 0.69 & 0.97 & 0.61 & 3.51 & 4.79 & 4.29 & 1.93 & 85.9 & 0.54 \\
\hline
\end{tabular}

Table 3. Phenology, yield contributing characters and yield of lentil as affected by varieties

\begin{tabular}{cccccccccc}
\hline Varieties & $\begin{array}{c}\text { Days to } \\
50 \% \\
\text { flowering }\end{array}$ & $\begin{array}{c}\text { Days to } \\
\text { maturity }\end{array}$ & $\begin{array}{c}\text { Plant } \\
\text { height } \\
(\mathrm{cm})\end{array}$ & $\begin{array}{c}\text { Plants } \\
\mathrm{m}^{-2} \\
(\text { no. })\end{array}$ & $\begin{array}{c}\text { Pods } \\
\text { plant } \\
1 \\
\text { (no.) }\end{array}$ & $\begin{array}{c}\text { Nodules } \\
\text { plant }^{-1} \\
(\text { no. })\end{array}$ & $\begin{array}{c}\text { Chlorophyll } \\
\text { index }\end{array}$ & $\begin{array}{c}\text { Yield } \\
\left(\mathrm{kg} \mathrm{ha}^{-1}\right)\end{array}$ & $\begin{array}{c}\text { *SB } \\
\text { disease } \\
(0-5 \\
\text { scale })\end{array}$ \\
\hline V1 & $59 \mathrm{a}$ & $108 \mathrm{a}$ & $34 \mathrm{c}$ & $135 \mathrm{c}$ & $81 \mathrm{c}$ & $59 \mathrm{c}$ & $14 \mathrm{a}$ & $1749.2 \mathrm{a}$ & $0.66 \mathrm{a}$ \\
$\mathrm{V} 2$ & $59 \mathrm{a}$ & $108 \mathrm{a}$ & $35 \mathrm{~b}$ & $143 \mathrm{~b}$ & $84 \mathrm{~b}$ & $63 \mathrm{~b}$ & $13 \mathrm{ab}$ & $1858.3 \mathrm{~b}$ & $0.4 \mathrm{ab}$ \\
$\mathrm{V} 3$ & $58 \mathrm{~b}$ & $107 \mathrm{~b}$ & $37 \mathrm{a}$ & $150 \mathrm{a}$ & $90 \mathrm{a}$ & $66 \mathrm{a}$ & $12 \mathrm{~b}$ & $1903.5 \mathrm{a}$ & $0.3 \mathrm{~b}$ \\
\hline $\mathrm{SE}$ & 0.17 & 0.3 & 0.29 & 1.02 & 1.27 & 1.50 & 0.83 & 32.5 & 0.15 \\
Lsd & 0.35 & 0.62 & 0.61 & 2.15 & 2.65 & 3.14 & 1.74 & 66.6 & 0.32 \\
$(.05)$ & & & & & & & & & \\
\hline
\end{tabular}


Table 4. Phenology, yield contributing characters and yield of lentil as affected by the interaction of fertilizer management options and varieties

\begin{tabular}{c|c|c|c|c|c|c|c|c|c}
\hline Interaction & $\begin{array}{c}\text { Days to } \\
50 \% \\
\text { flowering }\end{array}$ & $\begin{array}{c}\text { Days to } \\
\text { maturity }\end{array}$ & $\begin{array}{c}\text { Plant } \\
\text { height } \\
(\mathrm{cm})\end{array}$ & $\begin{array}{c}\text { Plants } \\
\mathrm{m}^{-2} \\
\text { no. })\end{array}$ & $\begin{array}{c}\text { Pods } \\
\text { plant } \\
(\text { no. })\end{array}$ & $\begin{array}{c}\text { Nodules } \\
\text { plant } \\
(\text { no. })\end{array}$ & $\begin{array}{c}\text { Chlorophyll } \\
\text { index }\end{array}$ & $\begin{array}{c}\text { Yield } \\
\left(\mathrm{kg} \mathrm{ha}^{-1}\right)\end{array}$ & $\begin{array}{c}* \text { SB } \\
\text { disease } \\
(0-5 \\
\text { scale })\end{array}$ \\
\hline FM1V1 & $59 \mathrm{~b}$ & 106 & $37 \mathrm{c}$ & $183 \mathrm{c}$ & 100 & 69 & $17 \mathrm{bcd}$ & $2221 \mathrm{~b}$ & $0.3 \mathrm{c}$ \\
FM1V2 & $58 \mathrm{bc}$ & 107 & $39 \mathrm{~b}$ & $192 \mathrm{~b}$ & 106 & 75 & $20 \mathrm{ab}$ & $2260 \mathrm{~b}$ & $0.0 \mathrm{c}$ \\
FM1V3 & $57 \mathrm{bc}$ & 105 & $42 \mathrm{a}$ & $201 \mathrm{a}$ & 118 & 83 & $23 \mathrm{a}$ & $2535 \mathrm{a}$ & $0.0 \mathrm{c}$ \\
FM2V1 & $59 \mathrm{~b}$ & 108 & $36 \mathrm{~cd}$ & $181 \mathrm{c}$ & 96 & 65 & $10 \mathrm{ef}$ & $2031 \mathrm{~d}$ & $0.0 \mathrm{c}$ \\
FM2V2 & $60 \mathrm{a}$ & 107 & $36 \mathrm{c}$ & $182 \mathrm{c}$ & 96 & 68 & $10 \mathrm{ef}$ & $2134 \mathrm{bc}$ & $0.3 \mathrm{c}$ \\
FM2V3 & $58 \mathrm{bc}$ & 106 & $39 \mathrm{~b}$ & $194 \mathrm{~b}$ & 104 & 73 & $15 \mathrm{~cd}$ & $2144 \mathrm{bc}$ & $0.6 \mathrm{bc}$ \\
FM3V1 & $59 \mathrm{~b}$ & 108 & $33 \mathrm{fg}$ & $135 \mathrm{e}$ & 79 & 57 & $19 \mathrm{bc}$ & $1835 \mathrm{e}$ & $0.6 \mathrm{bc}$ \\
FM3V2 & $59 \mathrm{~b}$ & 107 & $35 \mathrm{de}$ & $138 \mathrm{de}$ & 83 & 63 & $18 \mathrm{bc}$ & $1907 \mathrm{de}$ & $0.0 \mathrm{c}$ \\
FM3V3 & $59 \mathrm{~b}$ & 106 & $36 \mathrm{c}$ & $142 \mathrm{~d}$ & 85 & 65 & $4 \mathrm{~g}$ & $1847.7 \mathrm{e}$ & $0.0 \mathrm{c}$ \\
FM4V1 & $59 \mathrm{~b}$ & 109 & $33 \mathrm{fg}$ & $105 \mathrm{gh}$ & 70 & 59 & $16 \mathrm{bcd}$ & $1541 \mathrm{fg}$ & $0.0 \mathrm{c}$ \\
FM4V2 & $59 \mathrm{~b}$ & 109 & $33 \mathrm{fg}$ & $107 \mathrm{fg}$ & 74 & 58 & $7 \mathrm{fg}$ & $1571.7 \mathrm{f}$ & $0.3 \mathrm{c}$ \\
FM4V3 & $59 \mathrm{~b}$ & 109 & $34 \mathrm{ef}$ & $112 \mathrm{f}$ & 76 & 59 & $13 \mathrm{de}$ & $1662 \mathrm{f}$ & $0.6 \mathrm{bc}$ \\
FM5V1 & $61 \mathrm{a}$ & 110 & $31 \mathrm{~h}$ & $69 \mathrm{j}$ & 62 & 45 & $10 \mathrm{ef}$ & $1118 \mathrm{i}$ & $2.3 \mathrm{a}$ \\
FM5V2 & $59 \mathrm{~b}$ & 109 & $32 \mathrm{gh}$ & $98 \mathrm{i}$ & 63 & 51 & $11 \mathrm{ef}$ & $1418.3 \mathrm{gh}$ & $1.3 \mathrm{~b}$ \\
FM5V3 & $59 \mathrm{~b}$ & 109 & $32 \mathrm{gh}$ & $101 \mathrm{hi}$ & 66 & 52 & $4 \mathrm{~g}$ & $1328.3 \mathrm{~h}$ & $0.3 \mathrm{c}$ \\
\hline SE & 0.43 & 0.67 & 3.12 & 2.42 & 3.12 & 3.32 & 1.33 & 71.36 & 0.37 \\
Lsd (.05) & 0.95 & $\mathrm{NS}$ & 6.81 & 5.26 & $\mathrm{NS}$ & $\mathrm{NS}$ & 3.71 & 151.3 & 0.81 \\
\hline
\end{tabular}

\section{Conclusion}

The research revealed that yield and yield attributing characters of lentil were influenced by different fertilizer management options, varieties and their interaction effect. On the basis of this research findings it seems that vermicompost $1 \mathrm{t} \mathrm{ha} \mathrm{H}^{-1}+$ inorganic P:K:S @ 23:6:10 $\mathrm{kg} \mathrm{ha}^{-1}+2 \%$ DAP foliar spray with variety BARI Masur-8 is the best combination for maximizing the productivity of lentil. In general, it could be concluded that soil amendment with vermicompost, adequate inorganic fertilizer, foliar spray of nitrogenous and phosphorus fertilizer at pod initiation stage and with combined cultivation of high yielding variety such as BARI Masur- 8 maximized the productivity of lentil.

\section{Acknowledgement}

During the study period the colleague scientist and staffs of Regional Agricultural Research Station, Jashore and International maize and wheat improvwement center, Bangladesh Office have enriched this experiment by providing technical support. The experiment was conducted by the Regional Agricultural Research Station's regular fund.

\section{References}

Adolph, B., Butterworth, J. A., Satheesh, P. V., Reddy, S., Reddy, G. N. S., Karoshi, V., \& Indira, M. (2002). Soil fertility management in semi-arid India: its role in agricultural systems and the livelihoods of poor people. Study Report, NaturalResources Institute, University of Greenwich, 67, London.

Azad, A. K., Wahab, A., Saha, M. G., Nesa, Z., Rahman, M. L., Rahman, H. H., \& Amin, L. (2019). Krishi ProjuktiHatboi (Handbook on Agro-technology), $8^{\text {th }}$ edition. Bangladesh Agricultural Research Institute, Gazipur-1701, Bangladesh, 53-55. http://www.bari.gov.bd

BBS (Bangladesh Bureau of statistics). (2019). Yearbook of Agricultural Statistics-(2017-2018), 36-101. Retrieved from http://bbs.portal.gov.bd/sites/default/files/files/bbs.portal.gov.bd/page/1b1eb817_9325_4354_a756_3d1841 
2203e2/Yearbook-2017-Final-05-05-2018.pdf

Das, S. K., \& Jana, K. (2015). Effect of foliar spray of water soluble fertilizer at pre flowering stage on yield of pulses. Agric. Sci. Digest., 35(4), 275-279. https://doi.org/10.18805/asd.v35i4.6858

Fatima, K., Ganie, S. A., Yogesh, K., Masoodi, T. H., \& Ali, Shah. (2018). Effect of Organic and Inorganic Fertilizer Doses on Growth and Yield of Lentil under Cold Arid Conditions of Ladakh. Int.J.Curr.Microbiol.App.Sci., 7(11), 1449-1455.

FRG (2012). Fertilizer Recommendation Guide. Bangladesh Agricultural Research Council. Farmgate, Dhaka 1215. 274 p. Retrieved from https://msibsri4313.files.wordpress.com/2013/10/frg_2005.pdf

Gan, Y. K. G., Hanson, R. P., Zentner, Selles, F., \& McDonald, C. L. (2005). Response of lentil to microbial inoculation and low rates of fertilization in the semiarid Canadian Praities. Canadian Journal of Plant Science, 847-855.

Retrieved

from http://research.ipni.net/research/nap.nsf/0/cc2a0644ed141b5485257bce005b8b57/\$FILE/SK-25F.Gan.pdf

Hossain, M. B., Snigdha, Roy., \& Shafiul Alam, A. B. M. (2018). Foliar application of di-ammonium phosphate and triple super phosphate on lentil at drought prone area of Bangladesh. J.BangladeshAcad.sci., 42(2), 211214. https://doi.org/10.3329/jbas.v42i2.40055

Hussain, S. G. (2016). Importance of Pulses in Food and Agriculture. Retrieved from https://www.researchgate.net/publication/326920228_Importance_of_Pulses_in_Food_and_Agriculture

Janloo, M., Gholipoutim, A. M. A., Tobeh, A., \& Mostafei, H. (2009). Study of effects of different levels of Nitrogen and Potassium on yield and yield components of rainfed Lentil. Plant Ecophysiology, 2, 91-94.

Janmohammadi, M., Yousuf Nasiri, Hamed Zandi, Mohsen Kor-Abdali, \& Naser Sabaghnia. (2014). Effect of manure and foliar application of growth regulators on lentil (Lens culinaris) performance in semi-arid highland environment. Botanica Lithuanica, 20(2), 99-108. https://doi.org/10.2478/botlit-2014-0013

Mandal, K. G., \& Majumdar, D. K. (2001). Agro-physiological characteristics of lentil in relation to irrigation, nitrogen and plant density. J. Interacademicia, 5(2), 156-161. Retrieved from http://www.idosi.org/aejaes/jaes8(2)/11.pdf

Maps.ie (A GPS Coordinates on Google Maps). Retrieved from https://www.maps.ie/coordinates.html

Math, G., Gurupad, B., \& Lalita, J. (2018). Integrated nutrient management in lentil. International journal of chemicalstudies, $\quad 6(6), \quad 201-202 . \quad$ Retrieved from https://www.researchgate.net/publication/329586370_Integrated_nutrient_management_in_lentil

Niri, H. L., Tobeh, A., Gholipouri, A., Zakaria, R. A., Mostafaei, H., \& Jammatie- Somarin, S. (2010). Effect of nitrogen and phosphorus on yield and protein content of lentil dry land condition. American Eurasian Journal of Agriculture and Environmental Sciences, 8(2), 185-188. Retrieved from http://www.idosi.org/aejaes/jaes8(2)/11.pdf

Palta, J. A., Nandwal, A. S., Kumari, S., \& Turner, N. C. (2005). Foliar nitrogen applications increase the seed yieldand protein content in chickpea (Cicer arietinum L.) subject to terminal drought. Australian J. Agric. Res., 56, 105-112. https://doi.org/10.1071/AR04118

Rabbi, A. K. M. Z., Paul, A. K., \& Sarker, J. R. (2011). Effects of nitrogen and molybdenum on the growth and yield of garden pea (Pisum sativum L.) IJBSM, 2(2), 230-235. Retrieved from $\mathrm{http}: / /$ pphouse.org/upload_article/18_prm_rabbi_gardenpea..pdf

Rudrappa, L., Purakayastha, T. J., Singh, D., \& Bhadrara, Y. S. (2006). Long-term manuring and fertilization effects on soil organic carbon pools in a Typic Haplustept of semi-arid sub-tropical India.Soil and Tillage Research, 88(1), 180-192. https://doi.org/10.1016/j.still.2005.05.008

Salisbury, F. B., \& Ross, C. W. (1985). Plant Physiology. 3rd ed. Wadsworth, Belmont, CA. 540.

Sarkar, A. (2004). A Success Story of "Fruitful Partnership between the Bangladesh Agricultural Research Institute and International Center for Agricultural Research in the Dry Areas". APAARI publication, 2004. Retrieved from http://www.apaari.org/wp-content/uploads/2009/05/ss_2004_01.pdf

Satyanarayana, V., Vara prasad, P. V., Murthy, V. R.K., \& Boote, K. J. (2002). Influence of integrated use of farmyard manure and inorganic fertilizers on yield and yield components of irrigated lowland rice.Journal of Plant Nutrition, 25(10), 2081-2090. https://doi.org/10.1081/PLN-120014062

Sharma, R. K. (1999). Chemical fertilizers can increase productivity. legumes Crop research, 18(1), 159-160. 
Singh, O. N., Sharma, M., \& Dash, R. (2003). Effect of seed rate, phosphorus and FYM application on growth and yield of bold seeded lentil. Indian J. Pulses Res., 16(2), 116-118. Retrieved from https://eurekamag.com/research/004/126/004126702.php

The financial express, 28 Feb, (2020). Pulses import rises amid static local output. Retrieved from https://thefinancialexpress.com.bd/trade/pulses-import-rises-amid-static-local-output-1582864009

Zeidan, M. S. (2003). Effect of sowing dates and urea foliar application on growth and seed yield of determinate faba bean (ViciafabaL.) under Egyptian conditions. Egypt J. Agron., 24, 93-102.

Zohary D., \& Hopf M., (2000). Domestication of plants in the old world. New York. https://doi.org/10.1006/anbo.2001.1505

\section{Copyrights}

Copyright for this article is retained by the author(s), with first publication rights granted to the journal.

This is an open-access article distributed under the terms and conditions of the Creative Commons Attribution license (http://creativecommons.org/licenses/by/4.0/). 